International Research Journal of Management, IT \& Social Sciences
Available online at https://sloap.org/journals/index.php/irjmis/
Vol. 5 No. 6, November 2018, pages: 105 113
ISSN: 2395-7492
https://doi.org/10.21744/irjmis.v5n6.290

\title{
Human Behaviour in Keeping Dogs and Its Relationship to Rabies
}

\author{
Komang Hendra Setiawan ${ }^{\mathrm{a}, \mathrm{d}}$ \\ Ari Natalia Probandari a,b \\ Eti Poncorini Pamungkasari ${ }^{\text {b }}$ \\ Didik Gunawan Tamtomo ${ }^{\mathrm{a}, \mathrm{c}}$
}

Article history:

Received: 5 July 2018

Accepted: 30 September 2018

Published: 22 November 2018

\section{Keywords:}

dog;

human behavior;

participation;

rabies;

risk factors;

\begin{abstract}
This study was a qualitative study that conducted in Bali, Indonesia. Bali has been an endemic of rabies since 2008. Many factors have been related to rabies. One of them is human behavior. This research was focused on human behavior in keeping dogs and its relationship to rabies. The study was conducted in 3 villages at Buleleng regency where positive rabies dogs have been found in 2017. There was a high population of dogs in the villages, and most of them lived wildly. Data were collected through document review, interview, and direct observation. After being collected, they were analyzed using content analysis. Results of this research show that most of the villagers had been aware of rabies, but has got poor knowledge about it. They did not know how to prevent it, especially on how to threat wound caused by rabies dogs' bite. Furthermore, the villagers did not give any vaccine to their dogs. They only waited for the vaccine officer from the government to come to their house. The main problems in preventing rabies, related to human behavior, based on this research are: 1) lack of village's leaders involvement, especially in controlling and administering prevention program, 2) lack of people respond in controlling dogs population and dogs mobility, 3) lack of active participation of dogs owners to vaccinate their dogs and 4) lack of people knowledge about PEP procedures.
\end{abstract}

2395-7492@ Copyright 2018. The Author. This is an open-access article under the CC BY-SA license (https://creativecommons.org/licenses/by-sa/4.0/) All rights reserved.

\section{Author correspondence:}

Komang Hendra Setiawan,

Faculty of Medicine, Universitas Pendidikan Ganesha, Singaraja, Indonesia

Doctoral Program of Medical Science, Faculty of Medicine, Universitas Sebelas Maret, Surakarta, Indonesia

Indonesia, Email address: komanghendras@gmail.com

\footnotetext{
a Doctoral Program in Medical Science, Postgraduate Program, Universitas Sebelas Maret, Surakarta, Indonesia

b Department of Public Health, Faculty of Medicine, Universitas Sebelas Maret, Surakarta, Indonesia

c Department of Anatomy, Faculty of Medicine, Universitas Sebelas Maret, Surakarta, Indonesia

d Department of Public Health, Faculty of Medicine, Universitas Pendidikan Ganesha, Singaraja, Indonesia
} 


\section{Introduction}

As has been released by the World Health Organization (WHO), rabies is one of the diseases that included in the list of neglected tropical diseases. Rabies caused by rabies virus, which is a kind of the family Rhabdoviridae within genus Lyssavirus. This disease can be transmitted to humans through the bite of infected animals such as dogs, cats, bats, foxes, and others. It is recognized that dogs are the largest population of animals that transmitted rabies to a human. Rabies disease can be prevented by dog vaccination (Wei, et al, 2018; Zhu \& Guo, 2016).

There are two clinical type formS of rabies in human, furious (encephalitis) and paralytic. Furious form in human shows hypersalivation, agitation, hydrophobia. When the infected human offered with water, it will lead to pharyngeal spasms and involuntarily refusal of the water. The paralytic form of rabies differs from the furious form in that muscle weakness develops early. Both types leads to death but progression to death in paralytic type usually takes longer than furious form (Fooks et al., 2014).

Rabies is very fatal to a human, the best way to fight rabies is by doing prevention well. Vaccinating dogs known to be the best way to prevent rabies, also controlling their population and mobility, especially stray dog. People participation is very needed for this prevention. Increasing people knowledge and awareness about rabies will improve rabies prevention behavior in the community (Tenzin, 2017; Sambo 2014).

Rabies mostly spread in Africa and Asia including Indonesia. Bali, one of the provinces in Indonesia has reported rabies cases sine 2008. First in Badung regency then rabies is endemic to all districts in Bali. Data reports from Bali Provincial Health Agency showed that cases of rabies in human were 8,1,2 and 15, respectively in 2012, 2013, 2014 and 2015. While cases of rabies intermediary animals bite as much 44690, 46877 and 42630 respectively, in 2013, 2014, and 2015 (Dinas Kesehatan Provinsi Bali, 2015).

Buleleng is one of the nine regencies in Bali. In 2015, 6 rabies in human cases found in Buleleng. It was the highest number among another regency. The population of dog also high in this regency. Therefore, this study was conducted in Buleleng to examine human behaviour in taking care of dogs as the risk factor of rabies.

\section{Materials and Methods}

In conducting this study, the researchers utilized qualitative methods in health sciences. A qualitative method was utilized in order to describe human behavior in taking care dogs as the risk factors of rabies in Buleleng districts, Bali province, Indonesia. Qualitative research is essential in observing people in their environment, that we could interact with the people, trying to understand their language and gaining their own interpretation and understanding that related to the phenomenon around them.

The following exploratory steps undertaken by the researchers are 1. Literature reviews to reach out the findings of previous studies and the current knowledge about rabies; 2. Built formulations of the problem to be investigated; 3 . Interviewed the officers of agriculture department (that has a responsibility to animal health), and also interviewed health department officers in Buleleng; 4. Selected research sites, which in Ularan, Munduk and Suwug Villages that have infected canine in 2017; 5. Interviewed the head of villages; 6 . Prepared ten respondents from each village with purposive sampling - the respondent were chosen by the criteria that they keep dog/s as their pet and agreed to participate in the research; 7. Collected data through in-depth interviews with adult members of the households, capturing precisely about home environmental by direct observation and collect documents about the dog's vaccination status. Finally, the data that have been collected through the study of literature, observation, and scripts interview were analyzed using content analysis. Then, data retrieval research was conducted in February-July 2018.

\section{Results and Discussions}

Through an interview with a representative of agriculture department and through documents review, it is found that there are 128 villages in Buleleng, and canine rabies cases were found in 56, 33 and 17 villages respectively in 2015, 2016, and 2017 (primary data taken from agriculture department). The decrease of canine rabies spread believed to be the result of mass canine vaccination programme which conducted several times by the government.

Although there was a decreased number, until the very end of 2017, canine rabies was still found in Buleleng region. Data obtained from the research shows that there are several problems related to human behaviour which 
influence rabies prevention. Primary data obtained were analyzed using content analysis, extract it into meaning unit, code, category, and theme. Summary of the analysis is shown in following table 1.

Table 1

Content analysis of research data

\begin{tabular}{|c|c|c|c|}
\hline Meaning unit & Code & Category & Theme \\
\hline $\begin{array}{l}\text { Most People did not bring their } \\
\text { dog to us (the vaccine officers) }\end{array}$ & $\begin{array}{l}\text { Did not bring the dog to } \\
\text { the vaccine center }\end{array}$ & \multirow{3}{*}{$\begin{array}{l}\text { Lack of active participation of } \\
\text { dogs owners to vaccinate their } \\
\text { dogs }\end{array}$} & \multirow{15}{*}{$\begin{array}{l}\text { Problems in } \\
\text { preventing } \\
\text { rabies }\end{array}$} \\
\hline $\begin{array}{l}\text { I wait for the officer to come to } \\
\text { my house to vaccine my new } \\
\text { adopted dog }\end{array}$ & $\begin{array}{l}\text { Waiting for vaccine } \\
\text { officer to come }\end{array}$ & & \\
\hline $\begin{array}{l}\text { Their dog keep free, we (the } \\
\text { vaccine officers) need to catch } \\
\text { them first before giving the } \\
\text { vaccine }\end{array}$ & Dog keep free & & \\
\hline $\begin{array}{l}\text { We (Village officer) don't have } \\
\text { any data about dog vaccination } \\
\text { program }\end{array}$ & $\begin{array}{l}\text { No data about the } \\
\text { vaccination program }\end{array}$ & \multirow[b]{2}{*}{$\begin{array}{l}\text { Lack involvement of villages } \\
\text { government }\end{array}$} & \\
\hline $\begin{array}{l}\text { Awig-awig (Literary in Balinese } \\
\text { languages) here doesn't arrange } \\
\text { principles in carrying dog } \\
\text { properly }\end{array}$ & $\begin{array}{l}\text { No rules about how to } \\
\text { keep the dog }\end{array}$ & & \\
\hline $\begin{array}{l}\text { Dogs play a role as a house } \\
\text { guard, move around the house }\end{array}$ & & \multirow{3}{*}{$\begin{array}{l}\text { Lack of responsibility in } \\
\text { controlling dogs population } \\
\text { and mobility }\end{array}$} & \\
\hline $\begin{array}{l}\text { Dogs doesn't have special food } \\
\text { container, so it moves around to } \\
\text { find food where ever the owner } \\
\text { put it }\end{array}$ & $\begin{array}{l}\text { Dogs not tied up or put } \\
\text { in the cage }\end{array}$ & & \\
\hline Many dogs not castrated & Dogs not castrated & & \\
\hline $\begin{array}{l}\text { Many people came to the health } \\
\text { center to get the vaccine but } \\
\text { without cleaning the wound } \\
\text { properly }\end{array}$ & $\begin{array}{l}\text { Not cleaning the wound } \\
\text { properly }\end{array}$ & \multirow{3}{*}{$\begin{array}{l}\text { Lack of knowledge and practice } \\
\text { about PEP }\end{array}$} & \\
\hline $\begin{array}{l}\text { I clean the bite wound with } \\
\text { water and soap less than } 5 \\
\text { minutes }\end{array}$ & $\begin{array}{l}\text { Cleaning for less than } 5 \\
\text { minutes }\end{array}$ & & \\
\hline $\begin{array}{l}\text { I threat the bite wound with } \\
\text { traditional oil }\end{array}$ & $\begin{array}{l}\text { Threat with traditional } \\
\text { oil }\end{array}$ & & \\
\hline We own dog as a guard & Dog as a house guard & \multirow{4}{*}{ Reasons to keep dogs } & \\
\hline $\begin{array}{l}\text { The children love playing with } \\
\text { the dog }\end{array}$ & Dog as playmate & & \\
\hline $\begin{array}{l}\text { The dog is very loyal to the } \\
\text { owner }\end{array}$ & The dog is very loyal & & \\
\hline $\begin{array}{l}\text { Mahabaratha (One of the great } \\
\text { literature in Hindu) said that } \\
\text { Yudistira climbing great } \\
\text { mountain accompanied by a } \\
\text { loyal dog }\end{array}$ & $\begin{array}{l}\text { The dog is mentioned in } \\
\text { Hindu literature as a } \\
\text { loyal animal }\end{array}$ & & \\
\hline
\end{tabular}

The most effective way of preventing rabies is by vaccinating dogs. The problem in conducting mass dog vaccination is lack of active participation from people care dogs. When mass vaccination was held, most of the people did not want to come and bring their dog because of varies reasons. So, the officers must come to every household to give vaccine

Setiawan, K., Tamtomo, D. G., Probandari, A. N., \& Pamungkasari, P. (2018). Human behaviour in keeping dogs and its relationship to rabies. International Research Journal of Management, IT and Social Sciences, 5(6), 105-113. https://doi.org/10.21744/irjmis.v5n6.290 
and sometimes dogs are kept free and it gives more problem for the programme. This condition was reflected in the interview excerpts with an officer from the agriculture department.

“... Most people did not bring their dog to us, so we must come to their house to see the dog, and mostly the dog keeps free.. it gives us more problem.."

To make the vaccination programme more effective, minimum $70 \%$ of dogs population must be vaccinated every year (Lavan, et al, 2017; WHO, 2015). Data from the health department which obtained by documents review shows that there are 6, 1 and 1 human rabies cases respectively, in 2015, 2016, and 2017 in Buleleng. It showed that rabies is still a threat in this regency (Dinas Kesehatan Provinsi Bali, 2015; Dinkes Buleleng, 2017).

Interviews with a representative from the health department show that there are several health centers owned by government provide anti-rabies vaccine for human in Buleleng. Rabies vaccine is free of charge. People who seek for the vaccine are one who gets bite wound from dogs or cats. The problems are many people did not treat the wound properly before seeking vaccine. It was reflected in the interview excerpts with the officer from the health department (Adnani et al., 2018).

“... many people came to our health center to get vaccine.. but most of them came without cleaning the wound immediately with clean water and soap before..."

The lack of people knowledge and awareness in preventing rabies leads to improper PEP practice (Liu Q, et al, 2017). Next, bite wound should be treated by doing post-exposure prophylaxis properly. First, the wound must be clean immediately by soap and water flow for 15 minutes then giving disinfectants such as alcohol or iodine. After that, the patient should go to the health center to get the vaccine or to get other treatment according to the condition. Cleaning bite properly is very important because it can kill most of the viruses (Statistics, 2014).

Based on an interview with the head of villages, it has found that social canine vaccination had been done several times in their village, none of them remember how many times exactly it has been done. No written document about the number of dogs that have been vaccinated and the identity of dogs (or the owner of dogs) was recorded. This was reflected in the interview.

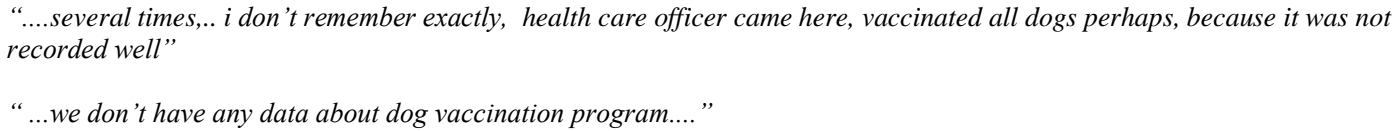

Exploring the documentary data at Village Government Office, that obvious data of the mass vaccination should be found, no data found about that program.

There are no regulations found governing the control of the dog population or the number of dogs that may be owned by people in villages. There are no regulations governing also for the obligations of dog owners to keep their dog to remains in their home environment only and not become a stray dog. Reflected as in the following quotation:

“... for people here in, awig-awig (literary in the Balinese language means customary manners as law in the village) doesn't arrange principles in carrying dog properly..."

From a recorded interview with the head of villages, it recognized that village administrators had no role in rabies prevention that ought to involve all of the people who lives in villages. The rules of rabies prevention in socio-cultural context should be:

a) Building people awareness about rabies as a preventable disease.

b) Promote responsible dog-ownership including dog vaccination and population management.

c) Improve bite prevention and post-exposure prophylaxis (PEP) practice.

d) Encourage community engagement in rabies prevention activities (WHO, 2015).

It is obviously important involving a village officer in prevention and mitigating rabies by established rules and monitoring that program as mentioned above.

Under the head of the villages, there is a chief who acts as a leader in the hamlet. The interview with the head of the hamlets found that all the hamlets in their village ever done mass dogs vaccination. But there is no document that records when the activity was carried out, how many dogs were given the vaccine and the identity of dogs in the vaccine. This is consistent with the data taken from interviews with heads of the village. Each hamlet has no special program to resolve the spread of rabies. 
Natural data had been goals of in-depth interviews with adults, whose members of households in 3 villages (Ularan, Munduk and Suwug villages) which been chosen purposively. The number of subjects is 10 each village (total 30 subjects) and they all have dog/s as their pet. Table 2 showed demographics data due to the highest educational level of the family as respondents.

Table 2

Demographic data of subjects

\begin{tabular}{ll}
\hline Criteria & $n(\%)$ \\
\hline Genders & $18(60 \%)$ \\
Male & $12(40 \%)$ \\
Female & \\
& \\
Education level & $3(1 \%)$ \\
Elementary school & $10(33 \%)$ \\
Junior high school & $17(66 \%)$ \\
Senior high school & 0 \\
College & \\
\hline
\end{tabular}

Source: Primary data, Feb 2018

Interviews and observations conducted with the dog owner households as respondents in this study. Observations to their house and their environment did see the how the house conditions compared with healthy house requirements, such as the condition of the floor, the air circulation, the source of the light, availability of healthy latrines, clean water sources and to see the conditions of dogs they have.

The results of observation show that the whole house is already using good materials for floor, ventilation, and resources sufficient for sunlight entered. All villagers have clean water resources. All the houses in the observation already have healthy latrines. All of 30 house observed conclude fulfill the requirements of healthy housing.

Although the house conditions are quite good, otherwise there was a phenomenon of many dogs found roaming, either move about freely outside or in the yard. This phenomenon occurs in all 3 villages observed. Some of these dogs wear necklaces identity, but some of them didn't wear a necklace of identity.

Dog owners said that there are some reasons to have a dog in their house. Dogs could give precaution security in the home environment as a watchdog. For example, if a stranger had entered the house, the dog would bark. The other reason is companionships. Dogs especially puppies are also maintained as a playmate, especially for children. Those statements reflected in the script of the interview:

\footnotetext{
"... We owned a dog as a guard dogs, as a security officer at home, for example, if there are thieves who entered the house. "

“... The children love playing with dogs, especially puppy .. if you do not have a dog, it seems to feel lonely"
}

People believe that dogs are the most loyal animal. All of the respondents, like most of Bali population religion, is Hindu and in Hindu's, there is an epic story about Yudistira (Older brother of 5 Pandawas) who climb the great mountain and directly goes to heavens was accompanied by a loyal dog. That is also the reason why people in Bali choose dogs as their pet. Showed by following quotation.

\footnotetext{
“... Mahabaratha said that King Yudistira goes to heaven through climbing Himalaya mountain accompanied by a loyal dog...”

“...we don't need to question about dogs loyalty .. our wife can betray us...but not our dog...”
}

People obtained puppies from the neighbor's dog breed or taken from other villages. Pet dog left to roam and not in a cage, in order to keep watch as a guard around the yard. In addition, pet owners also felt compassionated, if the dog tied up or caged. Pet dogs given a necklace as an identity, but many of these dogs were lose it and had not rigged the necklace again. There were found of some dogs have castrated or their testicles were being removed, but the other dogs were not. Dogs that were not castrated will continue reproductive, and then the number of dog population increases.

Setiawan, K., Tamtomo, D. G., Probandari, A. N., \& Pamungkasari, P. (2018). Human behaviour in keeping dogs and its relationship to rabies. International Research Journal of Management, IT and Social Sciences, 5(6), 105-113. https://doi.org/10.21744/irjmis.v5n6.290 
Controlling the dog population by castration and controlling dog mobility by keeping them in a cage or tied it up are part of the rabies prevention action (WHO, 2015). This is not properly done in the villages observed. It became a factor in rabies spread. There was a unique culture about the way feeding dogs which founded through direct observation. People eating in a dining table is not common, some people used to eat outside the house and sit in front of their dogs. The dog will wait for the food remnants from their owners such as fishbone or others, to be thrown to them directly. Most of the dog does not have special food container, they just eat all around the house yard where ever their owner put the food.

When asked about the status of dog vaccination, 23(76\%) respondents said their dogs have been vaccinated. When asking about vaccination records, the respondents said that there was a special necklace, red necklace, given by the officer, but some dog had the necklace been separated and also lost. Some of the respondents said that their dogs were not involved in that mass vaccination, because they newly adopted a dog after vaccination is completed. Currently, they are only waiting for someday that the officer who came to administer the vaccine.

Vaccinating dogs is the most effective way to prevent an outbreak of rabies. Townsend et al in 2013 conclude from their results findings that the outbreak of rabies in Bali could conquer by dogs vaccination programme (Townsend et al., 2013). However, it's could be a success by involving management of factors associated with rabies prevention, one of which is the role of the dog's owner.

From the interview with the representative of the agriculture department, there is the center of animal health located in every district of Buleleng regency. But the officers are limited so the dog's owner should actively look for a vaccine for their dog anytime and keeps a record of the vaccination to be evaluated when needed sometimes.

At this one last year, as much as 2 respondents said that their family members have experienced dog bite, all of them did not treat the bite wound by cleaning it with water flow and soap for 15 minutes. One said it was clean by water and soap but when asked how long it been to clean up, they said less than 5 minutes. It was shown with the following quotation:

"... the bite wound was cleaned by water and soap.."

"... i think it was less than 5 minutes"

Other said threat bite wound using traditional oil. All two got the anti-rabies vaccine from the health center.

Wound care as a result of a dog bite prevention procedures should follow post-exposure prophylaxis (PEP) manners. PEP consists of wound care, administration of anti-rabies vaccine and administration of rabies immunoglobulin (RIG) as indicated. Animal bite wound threated immediately by washing the wound with running water and soap, detergent, or povidone-iodine for 15 minutes. Wound care is carried out immediately and the correct way would be able to save lives (Statistics, 2014). The lack of public knowledge about post-exposure prophylaxis will attempt to restrict efforts in order to eradicate rabies.

When there is a dog bite case happen, a dog that bites human was immediately arrested and killed because it was considered by the people that once tasted human blood, the dog would habitually to bite humans again. If the dog that bites cannot be captured, then the dog is left to move freely alone. Appropriate guidelines for the prevention of rabies, dogs that bite people should be arrested, locked up and remain fed for two weeks. If within two weeks the dog was dead, they should be reported to health officials to do a post-mortem examination.

Respondent was asked with questions to know their knowledge about rabies. The result was shown in table 3.

Table 3

Respondent knowledge and practice about rabies prevention

\begin{tabular}{lll}
\hline Criteria & \multicolumn{2}{c}{$\mathrm{N}(\%)$} \\
\cline { 2 - 3 } & Yes & No \\
\hline $\begin{array}{l}\text { Knows that rabies } \\
\text { is dangerous to }\end{array}$ & 30 & 0 \\
human & $(100 \%)$ & $(0 \%)$ \\
Knows rabies & & \\
transmission & 24 & 6 \\
Knows how to do & $(80 \%)$ & $(20 \%)$ \\
PEP & 18 & 12 \\
Their dog is tied & $(60 \%)$ & $(40 \%)$ \\
or locked up & 17 & 13 \\
\hline
\end{tabular}


Their dog is vaccinated last 1 year.

$27 \quad 3$

$(90 \%)$ 3 $(10 \%)$

Source: Primary data, Feb 2018

It was shown in table 2 that all the respondents know the dangers of rabies. But somehow there are many respondents doesn't know about the correct PEP procedures. This gap must be resolved by doing more effective health promotion to people. Eradication of rabies cant is done without the active participation of peoples who have direct interaction with dogs.

\section{Conclusion}

The result of the study reflects that community life in Buleleng can not be separated with dogs. There are strong boundary between human and dogs. In another hand there are rabies, one of the neglective tropical diseases which transmitted through dog-bites still threat the community. The main problems to fight rabies in Buleleng regency, Bali province are 1). the lack involvement of villages leaders in controlling and administering prevention program, 2). the lack of people responsibility in controlling dog population and mobility, and 3) the lack of active participation of dogs owners to vaccine their dogs and 4) the lack of people knowledge about PEP procedure.

Conflict of interest statement and funding sources

The authors declared that they have no competing interest. The study was financed by DRPM.

Statement of authorship

The authors have a responsibility for the conception and design of the study. The authors have approved the final article.

Acknowledgments

The authors would like to thank DRPM for their financial support for this research.

Setiawan, K., Tamtomo, D. G., Probandari, A. N., \& Pamungkasari, P. (2018). Human behaviour in keeping dogs and its relationship to rabies. International Research Journal of Management, IT and Social Sciences, 5(6), 105-113. https://doi.org/10.21744/irjmis.v5n6.290 


\section{References}

Adnani, H., Subiyanto, A. A., Hanim, D., \& Sulaeman, E. S. (2018). Health promotion in clean and healthy behavior programs in traditional markets. International Research Journal of Management, IT and Social Sciences, 5(4), 4652.

Bali, D. K. P. (2015). Profil Dinas Kesehatan Provinsi Bali tahun 2015.

Dinkes Buleleng. (2017). Profil Dinas Kesehatan Buleleng.

Fooks, A. R., Banyard, A. C., Horton, D. L., Johnson, N., McElhinney, L. M., \& Jackson, A. C. (2014). Current status of rabies and prospects for elimination. The Lancet, 384(9951), 1389-1399.

Lavan, R. P., King, A. I. M., Sutton, D. J., \& Tunceli, K. (2017). Rationale and support for a One Health program for canine vaccination as the most cost-effective means of controlling zoonotic rabies in endemic settings. Vaccine, 35(13), 1668-1674.

Liu, Q., Wang, X., Liu, B., Gong, Y., Mkandawire, N., Li, W., ... \& Shi, B. (2017). Improper wound treatment and delay of rabies post-exposure prophylaxis of animal bite victims in China: Prevalence and determinants. PLoS neglected tropical diseases, 11(7), e0005663.

Sambo, M., Lembo, T., Cleaveland, S., Ferguson, H. M., Sikana, L., Simon, C., ... \& Hampson, K. (2014). Knowledge, attitudes and practices (KAP) about rabies prevention and control: a community survey in Tanzania. PLoS neglected tropical diseases, 8(12), e3310.

Statistics H. (2014). WHO Guide for Rabies Pre and Post Exposure Prophylaxis in Humans General considerations in rabies Post-Exposure Prophylaxis ( PEP ).

Tenzin, T., Namgyal, J., \& Letho, S. (2017). Community-based survey during rabies outbreaks in Rangjung town, Trashigang, eastern Bhutan, 2016. BMC infectious diseases, 17(1), 281.

Townsend, S. E., Sumantra, I. P., Bagus, G. N., Brum, E., Cleaveland, S., Crafter, S., ... \& Gunata, I. K. (2013). Designing programs for eliminating canine rabies from islands: Bali, Indonesia as a case study. PLoS neglected tropical diseases, 7(8), e2372.

Wei, X. K., Xiong, Y., Li, X. N., Zheng, M., Pan, Y., He, X. X., ... \& Zheng, L. F. (2018). Vaccination demonstration zone successfully controls rabies in Guangxi Province, China. BMC infectious diseases, 18(1), 386.

WHO, OIE.(2015) Human and dog rabies vaccines and immunoglobulins: report of a meeting. Glob Elimin DogMediated Hum Rabies [Internet].1-19.

Zhu, S., \& Guo, C. (2016). Rabies control and treatment: from prophylaxis to strategies with curative potential. Viruses, 8(11), 279. 


\section{Biography of Authors}

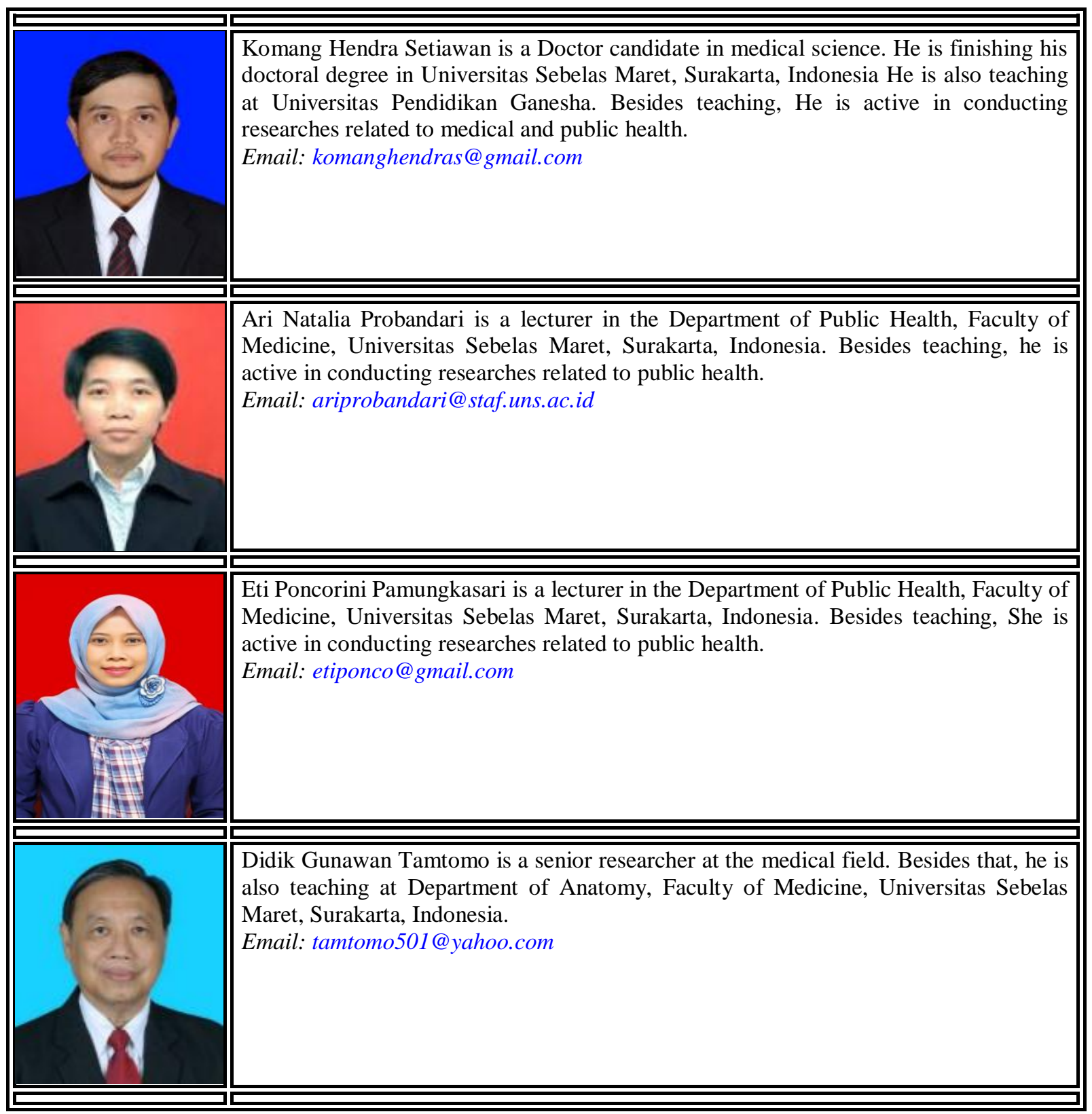

Setiawan, K., Tamtomo, D. G., Probandari, A. N., \& Pamungkasari, P. (2018). Human behaviour in keeping dogs and its relationship to rabies. International Research Journal of Management, IT and Social Sciences, 5(6), 105-113. https://doi.org/10.21744/irjmis.v5n6.290 